\title{
Sending Law to the Countryside and Conflicts between Villagers: A Rural Conflict Case from the Perspective of Anthropology Zhe-Chao SONG
}

China West Normal University, Shun Qing area of Nan Chong city of Si Chuan Province, China 526946387@qq.com

\section{Key words: Sending Law to the Countryside, Conflicts between Villagers, Anthropological} Thinking.

\begin{abstract}
Since the implementation of the reform and opening up policy, the rural society has changed drastically, such as great changes in the social order of the countryside and weakening of the social association. However, conflicts between villagers also increased. The notion of "sending law to the countryside" is to enhance the legal awareness of the farmers, the reconstruction of rural social order will by path. In recent years, the law has been widely spread in rural areas. It has penetrated into every corner of the rural society, and plays an important role in the process of conflict resolution, but not always has a positive effect. In this paper, through a case about one conflict in a village in Shanxi, we need to approach the relationship about "Sending Law to the Countryside and Conflicts between Villagers” from a different angle.
\end{abstract}

\section{Introduction}

"No-lawsuit" is the highest pursue of Chinese traditional society, it is the mainstream of Chinese peasants ' lawsuit view. "No-lawsuit" is a picture described by Fei Xiaotong about traditional Chinese rural society ${ }^{[1]}$. In the last century, the law started to gradually spread to rural society and has become a common approach of villagers to solve their conflicts. In the process of China's modernization, "socialist law-oriented country" is an inevitable trend, However, how much of this trend is conducive to resolving the conflict between the villagers? What are effects and responses?

\section{Problems and Approaches}

In ancient Chinese society, law is of great patriarch and endemicity [2] and was as a tool to assist governmental dictatorship [3] . During that perios, the national law does not extend to or affect the rural society, "National law only extends to the county level". The law is in a secondary position in the rural society. To resolve a dispute in China, "emotion" is considered first, then "courtesy", and "reason". The final option is to resort to "law"[4].

The Xin-Hai Revolution in China lifted the curtain of modernization. As a powerful weapon to maintain social order, the law has drawn wide attention, and legalization has become the only way to achieve modernization. Along with rural movements initiated by Yan Yang, Liang Shu-ming, Huang Yan-Pei and other people in various parts of China, situation of "National law only extend to the county level" has changed and the law rooted and blossomed in villages. In the 1930s and 1940s, Fei Xiao-Tong elaborated the importance and virtue of rule of law in rural society, opening a new chapter on relevant studies. But it was not until 1985 when the Communist Party of China (CPC) Central Committee and the Central propaganda Department of the State Council as well as the Ministry of Justice jointly formulated by the Declaration on basic knowledge of the law to all citizens after five years of planning, did the construction of rural social law in the modern sense receive national attention. Su $\mathrm{Li}$ proposed the theory of "send laws to the countryside" at the beginning of this century [5]. Since then, legal research began to shake off the shackle of the legal transplant, and pay more attention to the localization of law.

Scholars have studied the legal issues about the current rural society from different perspectives. Overall, legal practice of rural society through the traditional stage of "national law till the county" ,the stage of "pay attention to studies more than practice” from 1992 to 1985,the primary 
stage of legal practice in 1985,and the stage of "send law to the countryside" in the century. National law through various ways spread everywhere. And it becomes a very important aspect of social construction, providing a strong guarantee for the villager dispute resolution, but also a huge confusion. Such as the following case of a village in Shan-Xi Province.

\section{General Information of the Case}

It was in May 2015, during the break of the primary school in the village, Zhang San (alias), a senior pupil, bullied a junior student Li Si and caused minor injuries. Zhang San even hit the guard who came to stop the fighting. Later students who were present at that time informed their head teacher Mr. Fan. When Mr. Fan got no response from Zhang, he told the school president Chen (alias). President Chen sent student to ask Zhang again but still got nothing, then he decided to go to find Zhang himself. Zhang was rude when they met, and he yelled and called names towards President Chen. When the latter tried to pull him, Zhang almost tripped President Chen, who was a disabled person. President Chen thus kicked Zhang and slapped on his back and dragged him to the office and then called Zhang's mother. Learning the information, she just hit Zhang and apologized to Mr. Fan and President Chen before went home.

However, Zhang San's mother suddenly turned hostile after discussing it with her husband. In the afternoon, they went to school and said that President Chen had injured their boy, thus President Chen together with the family came to the local hospital, and paid the fees himself. The diagnosis showed that the boy was fine, but the parents insisted that their child was severely hurt and required hospitalization. The doctor interfered but the negotiation was unsuccessful. Two days later, Zhang San was led by their parents to be in a neighboring hospital.

Zhang San's parents took the issue to the county education department afterwards and informed the press. Reporters wanted to mediate the relations between the two sides, so the parents raised a claim as follow'" the teacher and headmaster are not to be allowed to teach in the school until Zhang San is 18.' 'The reporter failed to make them come to an agreement and did not broadcast the news.

In order to settle the dispute, people include president Chen, mediators of the village, the village chief and the teaching leaders all came to the family, and even the mayor also came to their home. Finally, Zhang San asked for 300,000 yuan as compensation. It was not agreed.

Village officials heard that Wang (alias), Zhang San's relative, works in the Public Security Bureau, thus asked him to be a mediator. Due to Wang's “interventions”, Zhang San proposed that president Chen compensate 85,000 yuan. The later disagreed and no settlement was reached.

Hereafter, the parents continued to report the situation to higher-level organizations. Under pressure from all levels, President Chen was removed from the principal positions. The town police station made administrative penalties for public security, and President Chen was punished to pay 500 yuan and to be detained for 10 days. At the same time,Zhang' s parents issued the event to the internet and took their child to a hospital in the city. They did prepare to sue.

After the end of the detainment, Zhang's parents sued President Chen officially for violating the right to Zhang San's health and asked 22680 yuan as compensation. The court accepted the case and issued subpoenas in January $2016^{[7]}$.

\section{Sending Law to the Countryside and Conflicts between Villagers}

\section{After Sending Law to the Countryside, Civil Mediation Was Weakened}

When the conflict began, mediation occurs first within the village community. The village has mediators responsible for the usual conflict. When the conflict happens, mediators responded firstly, then town and village cadres, all come to the home for mediation, but all ended in failure.

Civil mediation mechanisms play an important role in the history of China. Civil mediation put both sides on an equal position, relying on the "emotion" instead of "reason", Fei Xiaotong's idea of "no lawsuit", to a large extent, relys on civil mediation mechanism. In the acquaintance society, 
once the dispute between the villagers occurred, it will soon spread. Both sides hope to win, which requires a facilitator, in the traditional society, "chief" and "village head" "parents" are in the chrage, in modern society, there are a mediator to assume this responsibility.

\section{Law-the Tool of Interest Game}

The conflict, in the traditional Chinese society, can be quickly resolved internally through elders authority, etiquette and custom and its social impacts eliminated and traditional virtues carried forward. But in the legal community, with more frequent conflicts in rural social, they have become increasingly difficult to resolve. The law has often played a facilitating role in the process.as follows:

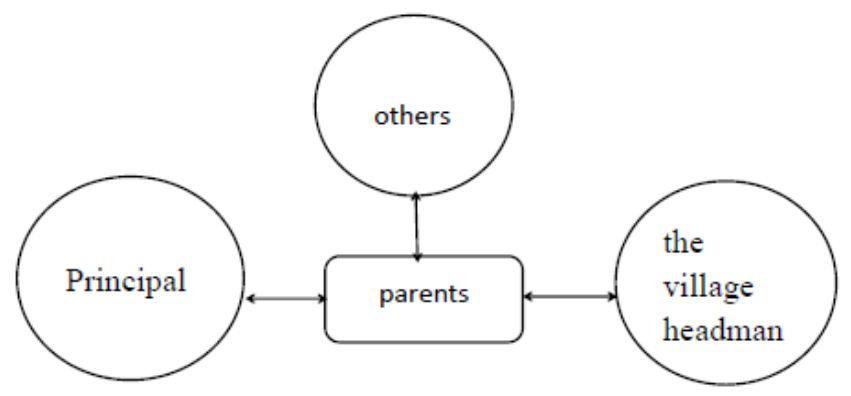

In this case, the cause of the incident is actually common in the countryside: in rural education there is a "consensus"——Spare the rod and spoil the child. Even though this "consensus" does not conform to the standards of modern society, it is normal in the rural society. Villagers generally regard the incident as "Parents blackmailing the principal since the principal discipline their children". From this perspective, the villagers generally considered the principal right whereas parents a bit unreasonable .

It can be said the case is a multilateral negotiation process from the start, as follows: The parent as the core. Headmaster, the village headman and other sides' negotiations with them all ultimately ended in failure. During the "Principal-parents" negotiation, principal apologized actively, but parents proposed huge compensation of requirements or to lawsuit; in the "parents-village headman" negotiation, village headman think since everyone live in the same village, it isn't necessary make a big deal out of this. However, parents think the principal broke the law so he must be held responsible; during the "parents-other sides" round of negotiation, the parents think the president has violated their children's right to health, so compensation must be paid, otherwise we will be in court to accuse.

It can be seen that in this negotiation process, the headmaster, the village headman and other sides consult with parents from the perspective of "emotion", hoping to resolve the conflict, but parents are occupy the "legal heights" by using the law as a bargaining chip to obtain compensation for their own benefits, or to meet their own requirements. Otherwise they will go to the court! The law becomes a powerful weapon in the game.

\section{The Nature of the Current Conflict in the Village}

In recent years the mainstream discourse of Chinese education is to ban corporal punishment, Because of this the mainstream discourse, it gives parents an opportunity, to use it to seek benefits, thus leading to deepening of the conflict. At this point, the conflict is no longer for rights but for compensation. Only when the headmaster gives parents compensation, and the amount meets the demand can this conflict be terminated

From this we can see that the core of the conflict is the interest. The essence of negotiations is "how much money". Compensation is the crucial link to solve villagers' conflicts. The amount can be agreed by both (multiple) coordination, or be a court decision. To finalize the amount of compensation and the final payment is to resolve the conflict. 


\section{Responses from the Rural Society}

The case occurred in May 2015 and deteriorated during the summer vacation. Zhang's parents spread the message on the internet, and exaggerate the facts. The news was viewed more than 8000 times, shaping the victim's identity; the principal struggles to cope with it. First he is dismissed as school president, then jail time, so what about responses of this case in the rural community? The following is an extract of the online message:

As netizen "c half light time 82251206"commented: the truth is that children love to bully others, he humiliate another child, Teachers cannot manage, the principal was angry.. The old headmaster so good a man would not be so savage and absurd!!

As netizen "He Youlai" commented I am also disgusted with corporal punishment, but I am more disgusted those student bullying people and beyond control. It must be reined it for a child like him."

As netizen"_7qbmyk18”you are not one-sided, to confuse the public. Do you really think that the public have no basic judgment? Advise not to take the child as weapon, parents are the child's best teacher, ask yourself, do you set a good example?[8]

we can get the conclusion that the villagers are negative towards parents' behavior because of the behavior violated the local knowledge. It is a kind of "obstinate residents" behavior with adverse influence and has attracted criticism from rural society.

\section{Summary}

From this dispute case in Shanxi Province, we do not make a judge of right or wrong, only from the case itself and the background of "send law to the countryside", making conclusions as following: the law have become a increasingly common means to resolve legal disputes, which makes the rural society to be a station from "no lawsuit" to "lawsuit". Law alienation is in the progress of "send law to the countryside", gradually become a catalyst of conflict, a tool of getting interests and a game tools of rural society. It is far away from the original intention of "send law to the countryside”.

Although in this case only the case, it reflects the reality of the rural community now ubiquitous This is just a case in Shanxi Province, but it reflects the reality of the rural society: while sending the law to the countryside, disharmony factors spring out in rural society where is not a harmonious, serene or acquaintance world. Split hides. So we need to alert the negative effects of sending the law to the countryside, to focus on legal education and propaganda, not articles of law but the legal function and obligation. We also need to play a moral role model of rural society and focus on training local consensus which can make the law be a pusher and make the rural society more harmonious.

\section{Acknowledgement}

It is very difficult for me to write in English, fortunately, I overcame this difficulty. Thanks to my supervisor Professor Tang Shao-Hong, he taught me how to write. Without his help, I could not complete this paper. Although this paper has been completed, there is still a need for improvement. I also need to thank other teachers and friends who have helped me.

\section{References}

[1]Fei Xiaotong, Native China.[M]. Beijing: Peking University Press, 2012.12.1.

[2]Xu Yong, Sending Law to the Countryside: a dual legal system of local social integration.[J]. ACADEMIC 2008 (3)

[3]John King Fairbank, The United States and China.[M].the commercial press, 1987. 
[4]Rene David, contemporary legal system.[M].Shanghai: Shanghai translation publishing house, 1984, p. 487.

[5]Su Li, "Sending law to the countryside grassroots judicial system" - China research [M]. Beijing: China University of Political Science and Law press.2000.

[6]YNG Xing."Dissemination of Law at Village Level”and“Access to Justice”- A Case Study of "Barefoot Lawyers"in the Villages of China. Tribune of Political Science and Law(Journal of China University of Political Science and Law)Vo .l 25,No. 1Jan. 2007

[7]Source: the complaint related materials about the case in zezhou county court.

[8]Source: http://v.youku.com/v_show/id_XMTI2MzIwMDkxMg==.html?from=s1.8-1-1.2: 